\title{
Guerrero, Coahuila, Mexico: A Guide to the Town and Missions
}

Jack D. Eaton

Center for Archaeological Research

Follow this and additional works at: https://scholarworks.sfasu.edu/ita

Part of the American Material Culture Commons, Archaeological Anthropology Commons, Environmental Studies Commons, Other American Studies Commons, Other Arts and Humanities Commons, Other History of Art, Architecture, and Archaeology Commons, and the United States History Commons

Tell us how this article helped you.

This Article is brought to you for free and open access by the Center for Regional Heritage Research at SFA ScholarWorks. It has been accepted for inclusion in Index of Texas Archaeology: Open Access Gray Literature from the Lone Star State by an authorized editor of SFA ScholarWorks. For more information, please contact cdsscholarworks@sfasu.edu. 


\section{Guerrero, Coahuila, Mexico: A Guide to the Town and Missions}

Creative Commons License

(c) (i) (8)

This work is licensed under a Creative Commons Attribution-NonCommercial 4.0 International License 


\section{GUERRERO, COAHUILA, MEXICO}

A Guide to the Town and Missions

Guía De La Ciudad y De Las Misiones

JACK D. EATON

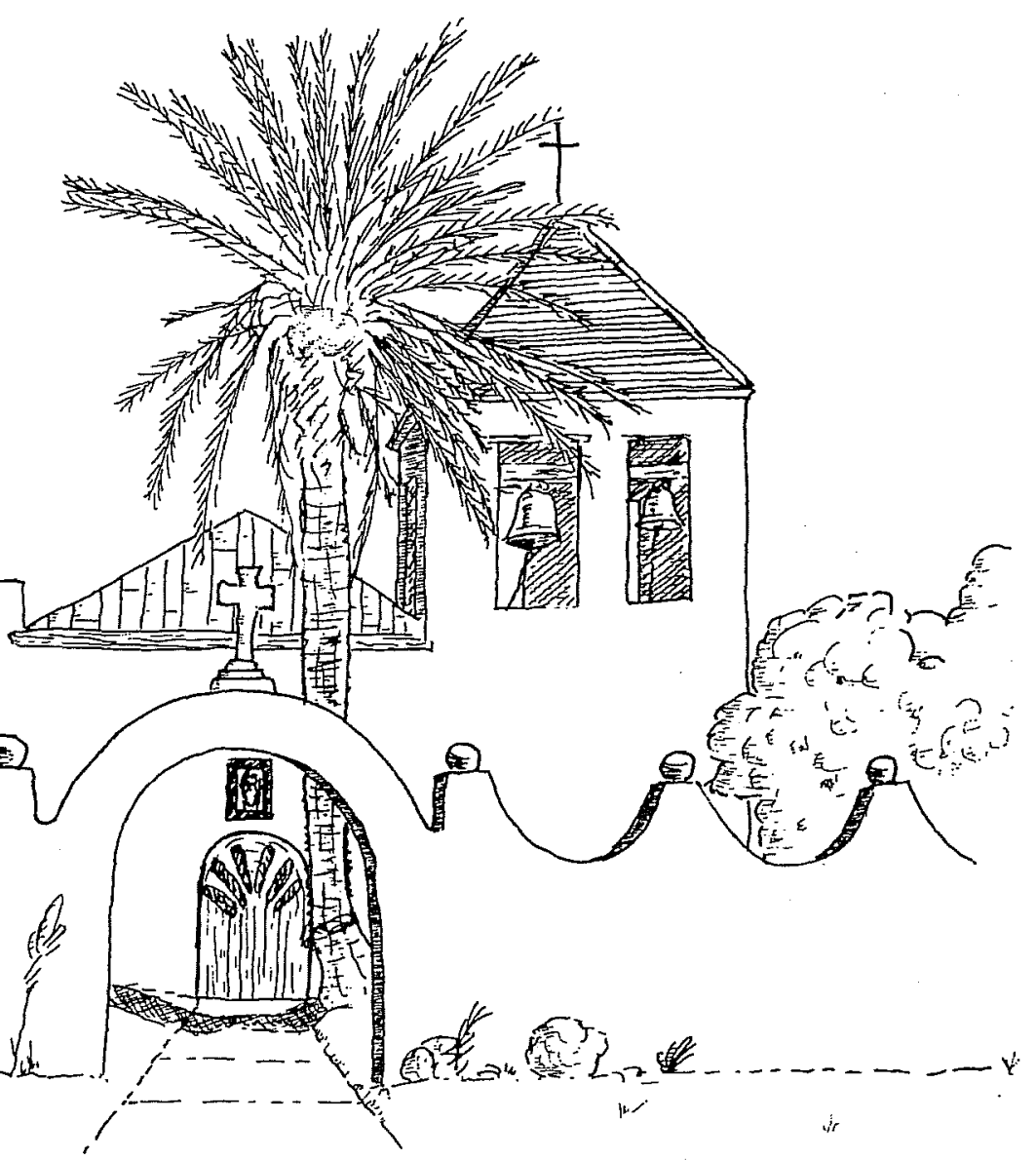

Spanish Translation by Wanda Kaufmann

Center for Archaeological Research

The University of Texas at San Antonio

Archaeology and History of the San Juan Bautista Mission Area,

Coahuila and Texas Report No. 4

1981 


\author{
Center for Archaeological Research \\ The University of Texas at San Antonio \\ 78285
}

Thomas R. Hester, Director

Archaeology and History of the San Juan
Bautista Mission Area, Coahuila and Texas

This series of publications presents information gathered from archaeological investigations and historical research at the Spanish mission complex in the area of Guerrero, Coahuila, Mexico. Additional volumes are forthcoming.

No. 1 (1979) Crossroad of Empire: The Church and State on the Rio Grande Frontier of Coahuila and Texas, 1700-1821. By Felix D. Almaraz, Jr. $\$ 5.00+.28$ tax for Texas residents.

No. 2 (1980) Inventory of the Rio Grande Missions: 1772; San Juan Bautista and San Bernardo. Translated and edited by Felix D. Almaraz, Jr. $\$ 5.00+.28$ tax for Texas residents.

No. 3 (1979) Ethnohistoric Notes on Indian Groups Associated with Three Spanish Missions at Guerrero, Coahuila. By T. N: Campbe11. $\$ 4.00+.22$ tax for Texas residents.

No. 4 (1981) Guerrero, Coahuila, Mexico. A Guide to the Town and Missions (Guía De La Ciudad y De Las Misiones). By Jack D. Eaton. Spanish translation by Wanda Kaufmann. $\$ 5.00+.28$ tax for Texas residents. 

GUERRERO, COAHUILA, MEXICO

A Guide to the Town and Missions Guía De La Cuidad y De Las Misiones

Jack D. Eaton

Spanish Translation by Wanda Kaufmann

Center for Archaeological Research

The University of Texas at San Antonio

Archaeology and History of the San Juan Bautista Mission Area, Coahuila and Texas, Report No. 4 



\section{TABLE OF CONTENTS}

Page

List of figures . . . . . . . . . . . . . . . . . . . . . i i

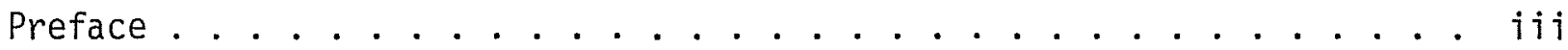

Guerrero, Coahuila, Mexico: A Guide to the Town and Missions. . . . . . . . . . . . . . . . . . . . . 1

Guerrero, Coahuila, Mexico: Guía de la Ciudad y de las

Misiones. . . . . . . . . . . . . . . . . . . 11

Figures (Figuras) . . . . . . . . . . . . . . . . . . . . . 23

Suggested Reading List. . . . . . . . . . . . . . . . . . . . . 41 


\section{LIST OF FIGURES}

Page

1. Map Showing Location of Villa de Guerrero and the Gateway Area . . . . . . . . . . . . . . . . 23 (Mapa que Muestra la Localizacion de la Villa de Guerrero y el Area de el Paso.)

2. Artifact Examples Collected from Area Survey and Mission Excavations. . . . . . . . . . . . . . 25 (Ejemplos de Artefactos Encontradas Superficialmente y en las Excavaciones de las Misiones.)

3. Map of Presidio de San Juan Bautista del Rio Grande. . . . . . . . . 27 (Mapa del Presidio de San Juan Bautista del Rio Grande.)

4. Street Map of Villa de Guerrero. . . . . . . . . . . . . 29 (Mapa de las Calles de la Villa de Guerrero.)

5. Presidio Period Structures in Guerrero . . . . . . . . . . . . 31 (Estructuras del Periodo del Presidio.)

6. Plan of Mission San Juan Bautista. . . . . . . . . . . . 33 (Plan de la Misión de San Juan Bautista.)

7. Mission San Juan Bautista. . . . . . . . . . . . . . 35 (Misión de San Juan Bautista.)

8. Views of Mission San Bernardo. . . . . . . . . . . . . . . 37 (Vista de la Misión de San Bernardo.)

9. Plan of Mission San Bernardo . . . . . . . . . . . . 39 (PTan de la Misión de San Bernardo.) 


\section{PREFACE}

This guide to the town and missions at Guerrero, Coahuila, is based largely upon the research efforts of the Gateway Project, an archaeological and ethnohistoric study of the area conducted by the Center for Archaeological Research, The University of Texas at San Antonio during 1975 to 1977.

Because the project was dealing with historic mission buildings which housed native American inhabitants of the region, the project had both historic and prehistoric aspects. The Indians gathered into the missions where inheritors of the native cultural tradition began at least 11,000 years ago. Therefore, an archaeological survey of prehistoric sites in the region of the missions, on both sides of the Rio Grande, was included in the study.

The excavations carried out at the missions located the buried remains of historic buildings which had been lost and forgotten for nearly a century. In addition, the sifting of the soils removed from the building remains provided both Spanish and Indian artifacts which were related to mission activities.

Ethnohistoric research focused on old Spanish documents which provided valuable additional information about the missionizing program at Guerrero, and also aided to illuminate the archaeological findings. The results of the Gateway Project are beginning to appear in a series of publications issued by the Center for Archaeological Research.

For several months during the Gateway Project, staff members lived in the town of Guerrero. The friendly relationship established with the towns' inhabitants was memorable and the aid provided by the Presidentes Municipal of the time, Sr. Victoriano Garcia P. and Sr. Ricardo Perez Treviño, is very much appreciated. Dr. Farias de los Santos and Sra. Jesuseña Flores Rodriguez provided housing for the project staff in Guerrero, and Sr. Julio Santos Coy of Piedras Negras aided us in several difficult matters. To them we are grateful. There are many others to whom we express our appreciation for help, especially those citizens of Guerrero who were employed by the project to work at the excavations.

The author of this guide, Jack D. Eaton, directed the field work at the missions and is therefore intimately familiar with the information he presents. Other project personnel included: Thomas R. Hester (Chief Archaeologist); Félix Almaráz, Thomas N. Campbe11, and Thomas C. Greaves (Ethnohistorians); Anne A. Fox (Ceramic Analyst); and J. Parker Nunley and Fred Valdez, Jr. (Archaeologists).

The project was performed under a permit issued by the Direccion de Monumentos Historicos del Instituto Nacional de Antropología e Historia. We are grateful to arquitectos Guillermo Bonfil Batalla, Sergio Zaldivar, Oscar Martinez, and Renề Villareal for their aid and collaboration. The project was funded by grants from the United States National Endowment for the Humanities, the Kathryn Stoner 0 'Connor Foundation, and the Sid Richardson Foundation. The University of Texas at San Antonio under President Peter T. Flawn provided administrative and logistical support. We are very grateful to all who have made the project possible. 


\section{GUERRERO, COAHUILA, MEXICO: \\ A GUIDE TO THE TOWN AND MISSIONS}

\section{A BRIEF BACKGROUND}

The modern town of Guerrero was originally the Spanish Colonial Presidio of San Juan Bautista del Rio Grande, around which there were three Indian missions. Settlement began with the founding of mission San Juan Bautista in 1700, followed by the establishment of missions San Francisco Solano and San Bernardo, and the military presidio, which was charged with the responsibility for guarding the missions. The presidio and nearby missions, located only a few miles from three important "pasos" or fords across the Rio Grande, formed the principal access, or gateway, to the vast and unsettled area to the north.

The settlement which eventually became San Antonio, Texas, began with the founding of mission San Antonio de Valero in 1718 by Franciscans and Indian neophytes coming from the Rio Grande missions. Therefore, important in its own right as an outpost of the Spanish empire, and connected by historical ancestry with one of the largest cities in Texas, the town of Guerrero is well worth visiting.

In Guerrero one is confronted with a modern community which is still largely laid out on the lines of the colonial presidio and in which many of the colonial houses are still in use. At San Bernardo mission just northeast of town stands the old church built in the 1760s. It is an interesting and impressive example of Spanish Colonial architecture and represents the only standing remains of the famous missions. 


\section{LOCATION AND HOW TO GET THERE}

Guerrero is located about 35 miles downstream from Piedras Negras, Coahuila, and is accessible by road from that town (Fig. 1). Coming from Mexico, the easiest route is by way of Monclova north on Mexico's national Highway 57, to the junction with Highway 2, which leads to Guerrero 30 miles distant. From the United States, the town is accessible through Eagle Pass, Texas, across the border to Piedras Negras and through that city on the Monterrey highway (Hwy 57) to the junction with Highway 2 south of Piedras Negras. One can easily leave San Antonio early in the morning, drive the 150 miles to Eagle Pass, Tunch in Piedras Negras, and drive on to Guerrero for the two or three hours of visiting needed to see the town and mission. Then, dependent on the visitor's stamina, one can either spend the night in Piedras Negras or return to San Antonio or Monclova. There are no tourist facilities in Guerrero at present (1978), al though simple meals and cold drinks are available. The visitor should have sufficient gasoline for about 60 miles round trip before leaving Piedras Negras.

\section{THE GATEWAY PROJECT}

The Gateway Project was an archaeological and historical study of the region on both sides of the middle Rio Grande and especially of the colonial missions near the town of Guerrero. Sponsored by The University of Texas at San Antonio and by the National Institute of Anthropology and History of Mexico, the project operated from 1975 until 1978. The Agency for Colonial Monuments in Mexico and the Ministry of Public Works stabilized the San Bernardo Mission Church. An architectural survey of the town of Guerrero was carried out earlier by the Texas Architectural Foundation and the School of Architecture of the University of Texas at Austin. Excavations at the mission sites were conducted 
by the Center for Archaeological Research. The University of Texas at San Antonio. Gateway Project personnel excavating the missions and analyzing artifacts lived in the town of Guerrero during the work seasons over a threeyear period. The people of the town and their officials were always very helpful and hospitable, and we therefore dedicate this small guide to them.

\section{THE NATIVE POPULATIONS OF THE AREA}

American Indian peoples occupied the middle Rio Grande area for more than 11,000 years before the Spanish conquest. Archaeologists working in Texas and Coahuila have found hundreds of campsites representing the hunting and gathering way of life of these peoples. The earliest evidence comes from the PALEO-INDIAN period, between 8000-9000 B.C., and consists of fluted projectile points, used in the hunting of mammoth, large bison, and other animals of the late Ice Age or Pleistocene. After the end of the Ice Age, around 7000-8000 B.C., PALEOINDIAN cultures persist until about 6000 B.C. From that time, up to about A.D. 1000, the region yields evidence of cultures of the ARCHAIC period. Artifacts include chipped stone projectile points (used on light spears, thrown with the atlate or spear-thrower), scrapers, knives, choppers, and ground stone slabs used for plant food processing. Sites are characterized by concentrations of these artifacts, along with large amounts of waste flakes (from tool manufacture), cooking hearths and scattered burned rock, and food remains (animal bones, musse1 shells, snail she11s). As a part of the Gateway Project, an archaeological survey team recorded more than 160 sites in the Guerrero area, on both sides of the Rio Grande. Most of these sites date to the ARCHAIC era. About A.D. 1000, archaeologists note a change in local cultures. These changes, during the LATE PREHISTORIC period, reflect new technologies such as the introduction of the 
bow and arrow and the manufacture of plain, reddish ceramics. Sites of this period are known on the Texas side of the river, but are very rare in the Guerrero area. In adjacent Texas, the LATE PREHISTORIC is also marked by the presence of large numbers of bison.

It must be pointed out that the environment used by these ancient hunting and gathering peoples was probably quite different than that we see in the region today. The terrain was probably a grassland savanna, with less mesquite (the mesquite "invasion" appears to have occurred within the last 300 years) and with more abundant water sources. Antelope, bison, bear, and gray wolf were among the animals present at that time, but absent in the region today.

When the Spanish arrived in the area, they found many small groups of hunters and gatherers. There was no formal tribal organization, but rather a pattern of mobile and dispersed groups, some of whom shared a common language, but with other languages used by some groups. Earlier anthropological studies have used the name "Coahuiltecan" for these peoples. However, it is now clear that they were diverse both culturally and linguistically, and that this term is no longer appropriate. It is unfortunate that the Spanish left so few records of these peoples, because with the arrival of Europeans, these native groups broke up--some taken into the missions (as was the case in the Guerrero area), and others destroyed by the introduction of various diseases. In the Guerrero missions, we find the surviving cultural remains of these native peoples--their chipped stone tools and pottery, and the artifacts which they adopted from the Spanish during the mission period (Fig. 2). By the early 1800s the native peoples were no longer recognizable. Many of the small groups had become extinct, but others had become part of the Spanish culture. 
With the demise of the native populations, much of northern Coahuila and southern Texas was uninhabited. Thus, intruding Indian groups such as the Apache and Comanche moved into the area, occupying it until the middle of the 19 th century.

\section{THE ARCHAEOLOGY AND HISTORY}

Presidio del Rio Grande and the Modern Town of Guerrero

The early 18th century Spanish settlement which eventually became the modern town of Vicente Guerrero began with the establishment of the military presidio called San Juan Bautista del Rio Grande del Norte. The presidio and nearly Indian missions, situated near important crossings of the Rio Grande, once formed the Gateway to Spanish Texas.

In 1701 a Flying Company (cavalry) consisting of 30 soldiers under the command of Captain Diego Ramón was assigned to protect the missions San Juan Bautista and San Francisco Solano which were founded the previous year by Franciscan missionaries. In 1702 Mission San Bernardo was also established nearby.

Then, in 1703, a formal presidio was laid out around a plaza (plaza de armas) consisting of 10 flat-roofed, stone and adobe structures. By the 1760 s the presidio was well established. Also by that time numerous houses belonging to military and civilian families were built around the presidio, forming a smal1 frontier settlement (Fig. 3).

A1though originally designed to protect the Indian missions, the presidio and the growing Spanish community around it continued to function as a bastion on the frontier long after the missions were secularized in 1797 and eventually abandoned. Presidio del Rio Grande ceased to exist as a military establishment 
around the mid-1800s, when military units and international traffic shifted to the towns of Piedras Negras and Laredo.

The center of Guerrero was the site of Presidio del Rio Grande (Fig. 4). When it was the military plaza it was an open field enclosed by presidio buildings, but today it contains a bandstand and park.

Little remains of the presidio buildings which once formed around the plaza. On the east side still stands the San Juan Bautista parish church (Fig. $5, a)$. Although construction of this church began early in the presidio period, it was not completed until the turn of the 19th century. While in construction, a smaller structure served the spiritual needs of the military and civilian families. The two bells of cast copper seen in the bell tower were hung there in 1851 to commemorate the 150th anniversary of the presidio. Normally the church is kept locked until a priest from Piedras Negras visits to conduct Mass or officiate other church services. The key to the church is kept in the City Hall (palacio municipal), and the church can be opened by request.

On the west side of the plaza, where there is now a school, was the site of presidio headquarters and the guardhouse (cuerpo de guardia). Soldiers' barracks were located on the north side where there is a private residence and a general store (Cooperativa Familiar), and also on the south side where City Hall now stands.

Just off the northwest corner of the plaza, on Calle Alama, is the presidio captain's house (casa del capitan). This house was built prior to 1776 and served as residence for the presidio commanders (Fig. $5, \mathrm{~b}$ ).

One block west of the plaza, on Calle Sanchez, is the Casa Botello. Currently a store and residence, this building was once the presidio paymaster's house. Another Spanish Colonial structure well worth visiting is on Calle 
Prieto, one block south of the plaza. In addition, there are many other buildings throughout Guerrero, some occupied and others in ruin, which date to the 18th and 19th centuries.

The main street running through Guerrero is Calle Raul Lopez Sanchez, once called Calle Real (Royal Street). From the plaza this street runs west past the site of Mission San Juan Bautista, a distance of about $1 \mathrm{~km}$. The site is on a hilltop on private land and there are now no visible ruins. Beyond the mission the old Camino Real (Royal Highway) turned south to Monclova and Mexico City.

The town cemetery (panteón), located on Calle Abasolo at the eastern side of town, has burial crypts dating to the Spanish Colonial period.

About $1 \mathrm{~km}$ north of the cemetery is Mission San Bernardo. Its location is noted by the large unfinished church. Beyond the mission the Camino Real once crossed the Rio Grande at Pasos Pacuache and Las Islas and led to San Antonio and the missions of east Texas.

Northwest of Guerrero is a long, narrow spring-fed lake called Los Banaderos. There are also two other natural springs (ojas de agua) called Las Brujas and Las Parritas which feed an easterly flowing channel called acequia ciénega on the north side of town. The water of the acequia once flowed over two small waterfalls (caida de agua), the second of which was dynamited early in this century. Beside the damaged dam is a stone quarry which supplied travertine blocks used in the construction of Mission San Bernardo. Just below the dam the visitor will see the acequia cut deeply into solid rock. Another old stone quarry, which probably furnished building material for Mission San Juan Bautista, is located near the Las Brujas spring.

An acequia system, built in colonial times, can still be seen providing channeled spring water throughout the settlement. 
San Juan Bautista Mission

San Juan Bautista was the first mission to be established at the Gateway area. Founded on New Year's Day in 1700 by Captain Diego Ramón and Fathers Antonio 01 ivares and Francisco Hidalgo, it was first located near where the presidio was situated. However, its exact location or any recognizable remains are currently unknown.

In the 1740s the mission was moved west of the presidio where it occupied a hilltop a suitable distance from the Spanish settlement (Fig. 4). Here it stood until it was abandoned sometime after the 1810 Revolution. In time, the buildings were demolished and most of the materials making up the mission complex were carried away to build houses in the town and nearby ranches. Today only a scrub- and cactus-covered hill marks the site of this once famous mission. In 1976, with permission of the land owner, the site was cleared as needed and selective excavations were conducted. The results of these excavations are shown in the ground plan of the mission complex (Fig. 6).

By selective trenching, the most important remaining architectural features of the complex were uncovered and recorded. In the best-preserved locations only foundations and flooring, and occasional sections of lower walls, remain. These were found buried under as much as 3 or 4 feet of debris and built-up soils (Fig. 7,a). After recording was complete, all excavations were backfilled to protect the remains.

The mission church was cruciform in plan with the entrance facing west. The walls were built of cut block and rubble fill set in lime mortar, and were plastered and whitewashed inside and outside. The floors were surfaced with ceramic tiles. On the north side of the entrance was the bell tower, and in the tower base was the baptistry. There was a main altar and two side altars. The sacristy consisted of two rooms on the south side of the sanctuary. 
South of the church was the monastery quadrangle. Within the walled enclosure were the living quarters and offices of the resident friars, as well as storerooms and workshops. The buildings were built of adobe bricks on stone foundations, and some floors were paved with ceramic tiles.

A large structure just to the south of the quadrangle was the granary where harvested grains (corn and beans) were stored. No walls remain, but excavations uncovered an elevated flagstone flooring.

Beyond the granary were long buildings which housed workshops, such as blacksmith and carpenter shops, and possibly weaving rooms.

Forming the southern area of the mission, and extending west, was a long structure which contained many small family apartments for the mission Indians. Only stone foundations remain. At the western end was a circular bastion forming part of the mission defense (Fig. 7,b).

San Bernardo Mission

San Bernardo Mission, founded early in 1702 by Captain Diego Ramón and Father Alonzo González, was located a short distance to the northeast of Presidio del Rio Grande (Guerrero) (Fig. 4). The large unfinished church of cruciform plan, built by Father Diego Jiménez during the 1760s, still stands to mark the site of this mission. This was the second church built at this mission, but all other buildings have disappeared since final abandonment of the complex. The standing church was stabilized in 1975 by the Ministry of Public Works under the direction of the Department of Colonial Monuments (INAH) (Fig. 8,a).

During 1975 and 1976 archaeological investigations were conducted to the north and northeast of the standing church. The buried remains of mission buildings were located by selective excavations. The results of this work have provided a ground plan of the principal buildings which comprised the mission (Fig. 9). 
Just north of the standing church were two rows of long buildings which had contained Indian family apartments and workshops. Only the stone foundations, buried under several inches of soil, were found (Fig. 8,b).

To the northeast of the standing church more buried foundations of mission buildings were uncovered and recorded. The large area between the two groups of structures, where there is now a picnic facility, was the mission quadrangle. No evidence of an enclosure was found, and perhaps one was not built.

The eastern group of structures comprised the original San Bernardo church and other structures which were the missionaries quarters and offices, storerooms and workshops.

The original church was a simple linear structure which remained in service probably until the mission was abandoned. It is not certain if the large standing church was ever consecrated and used for services.

After the excavations and recordings were completed, most of the remains were reburied to preserve them.

San Francisco Solano Mission

Little can be said about this mission which was founded only two months after Mission San Juan. The site of the mission is believed to have been located northwest of Guerrero (Fig. 4), but there are no structural remains visible to verify this, and excavations here were not undertaken.

Founded by Captain Ramón and Father Antonio 01 ivares, this mission remained less than three years at the Gateway area. Then, after a series of moves, it finally settled on the banks of the San Antonio River in Texas, where it was renamed Mission San Antonio de Valero, and was to eventually become a battle shrine known as the Alamo. 


\author{
GUERRERO, COAHUILA, MEXICO: \\ GUIA DE LA CIUDAD Y DE LAS MISIONES
}

\title{
HISTORIA BREVE
}

La ciudad que ahora se conoce como Guerrero fue originalmente el presidio español de San Juan Bautista del Río Grande, alrededor del cual se hallaron tres misiones.

La colonización empezó primero con la fundación de la misión de San Juan Bautista en 1700 y continuó con el establecimiento de las misiones de San Francisco Solano y de San Bernardo y del presidio militar cuya responsabilidad era la protección de las misiones.

El Presidio y las tres misiones, situadas a pocos kilómetros de tres importantes pasos del Río Bravo eran el punto de acceso hacia el vasto y deshabitado territorio del norte.

El poblado que eventualmente llegó a ser San Antonio, Texas, empezó su existencia en el año 1718 con la fundación de la misión de San Antonio de Valero por los franciscanos y los indios provenientes de las misiones del Río Grande. Por 10 tanto, la ciudad de Guerrero, que era importante por si sola como puesto avanzado del imperio español, también se relaciona historicamente a San Antonio, una de las mayores ciudades del estado de Texas, razon para lo que vale la pena visitarla.

En Guerrero, el visitante se encuentra con una ciudad moderna que está aún organizada según el plan del antiguo presidio colonial y en la cual muchas de las casas coloniales están habitadas. En la misión de San Bernardo, al noreste de la ciudad, está la antigua iglesia construida en el año 1760 . Este es un interesante e importante ejemplo de arquitectura colonial y el único vestigio en pie de las misiones famosas. 


\section{LOCALIZACION}

Guerrero está situado a 35 millas río abajo de Piedras Negras, Coahuila y es acesible desde esta ciudad (Fig. 1). Viniendo desde México, la ruta mas fácil es por Monclova, hacia el norte por la carretera número 57, hasta el cruce con la carretera 2 la cual 17ega a Guerrero que está a 30 millas de distancia. Desde los Estados Unidos se 17 ega a Guerrero por Eagle Pass, Texas, atravesando 1a frontera y la ciudad de Piedras Negras en dirección de Monterrey (carretera 57) hasta 1 legar al cruce con 1 a carretera numero 2, al sur de Piedras Negras. Se puede salir de San Antonio por la madrugada, recorrer las 150 millas a Eagle Pass, almorzar en Piedras Negras, y seguir rumbo a Guerrero para pasar dos o tres horas visitando la ciudad y la misión. Después, según el vigor del visitante, se puede pasar la noche en Piedras Negras o seguir para San Antonio o Monclova. Actualmente (1978) no hay acomodaciones para los turistas en Guerrero, aunque comidas y refrescos son obtenibles. El visitante deberá tener bastante gasolina para las 60 millas de ida y vuelta al salir de Piedras Negras.

\section{EL PROYECTO "GATEWAY"}

El Proyecto "Gateway" fue un estudio arqueológico e histórico de la región en ambos lados del Río Bravo medio y especialmente de las misiones coloniales en las cercanias de la ciudad de Guerrero. Patrocinado por la Universidad de Texas en San Antonio y por el Instituto Nacional de Antropología e Historia de México, el proyecto fue llevado a cabo entre 1975 y 1978. La Agencia de Monumentos Coloniales de México y el Ministerio de Obras Públicas reconstruyeron la iglesia de la misión de San Bernardo. Una inspección arquitectónica de la ciudad de Guerrero se hizo previamente por Texas Architectural Foundation y la Escuela de Arquitectura de la Universidad de Texas en Austin. Las exploraciones de las misiones fueron llevadas a cabo por el Centro de Investigación Arqueológica de 
1a Universidad de Texas en San Antonio. El personal del Proyecto Gateway que ha participado en las excavaciones de las misiones y en analizar los artefactos, permaneció trabajando tres años consecutivos en Guerrero y siempre fue muy bien acogido por los habitantes y oficiales de la ciudad. Por eso dedicamos a ellos esta guía.

\section{POBLACIONES INDIGENAS DE LA REGION}

Los pueblos indios ocuparon la región del Río Bravo medio por mas de 11,000 años antes de la conquista española. Los arqueólogos que trabajan en Texas y Coahuila han hallado centenares de campamentos que representan un modo de vida basado sobre la caza y la recoleccion. La evidencia más antigua viene del período PALEO-INDIO, entre 8,000 y 9,000 años A.C., y consiste de puntas de proyectiles acanaladas que fueron usadas en la caza de mamuts, enormes bisontes, y otros animales de la Epoca Glacial Tardía, o sea del Pleistóceno. Al terminarse 1a Epoca Glacial a los 7,000-8,000 años A.C. las culturas paleo-indias siguen existiendo más o menos hasta 6000 A.C. Desde esta fecha hasta alrededor de 1000 D.C. 1a región muestra evidencias de culturas pertenecientes al periodo ARCAIC0. Los artefactos incluyen puntas de proyectiles (usados como puntas de lanzas ligeras que se arrojaron por medio del atlat1, un instrumento para tirar lanzas), raspadores y cuchillos de piedra así como metates utilizados en la preparación de alimentos. Los sitios se caracterizan por concentraciones de estos artefactos y también de grandes acumulaciones de lascas residuales provenientes de la producción de utensilios de piedra, huellas de hogueras, piedras calcinadas y restos de comidas (huesos de animales, conchas de mejillón y de caracoles).

Como parte integral del Proyecto Gateway un equipo de reconocimiento arqueológico registró más de 160 sitios en la zona de Guerrero en ambos lados del Río Bravo. La mayoría de estos sitios datan del período Arcaico. Cerca 
de 1,000 años D.C. los arqueólogos notan algunos cambios en las cultural locales. Estos cambios, que aparecen durante el PERIODO PREHISTORICO TARDIO, reflejan nuevas tecnologías como la introducción del arco y flecha y la manufactura de una cerámica rojiza sin adornos. Los sitios de este período se hallan principalmente en la orilla texana del río y, son bastante raros en la región de Guerrero. En el estado vecino de Texas, el Prehistórico Tardío es también caracterizado por la presencia de un gran numero de bisontes.

Se debe señalar que el ambiente en que vivían estos antiguos pueblos de cazadores y recolectores era quizás bastante diferente del que vemos hoy día en 1a región. Probalemente el terreno estaba cubierto de una sabana de hierba y tenía menos mesquites (1a "invasión" del mesquite parece haber occurrido durante los ultimos 300 años) y también más fuentes de agua. El antílope, el oso, y el lobo gris habitaban la region en aquella época pero han desaparecido de la región hoy en día.

Cuando los españoles llegaron a la región, hallaron pequeños grupos de cazadores y pizcadores los cuales no tenían una organización tribal formal. Formaban una red de grupos móbiles y dispersos, algunos de los cuales compartían una idioma común mientras otros usaban diajectos distintos. Los primeros estudios arqueológicos usaron el nombre de "coahuiltecos" para designar a estos pueblos. Sin embargo, está claro ahora que ellos eran distintos unos de los otros, tanto cultural como linguísticamente y por 10 tanto el término usado previamente no es apropiado. Es una lastimá que los españoles hayan dejado pocos datos sobre esta gente porque, con la llegada de los españoles, se dispersaron. Unos fueron llevados a las misiones (come fue el caso en la región de Guerrero) y otros murieron por las enfermedades que los españoles introdujeron. En las misiones de Guerrero hallamos las huellas de las culturas de estos pueblos--sus utensilios 
de piedra tallado y su cerámica también como los artefactos que ellos adoptaron de los españoles durante el periodo misionero (Fig. 2). A principios del siglo XIX los pueblos indígenas ya eran irreconocibles. Muchos de los pequeños grupos se habían extinguido, pero otros se habían integrado a la civilización española.

Con la desaparición de las poblaciones indígenas, gran parte de Coahuila y de Texas se quedó inhabitada. Por 10 tanto grupos de otras regiones como los apaches y los comanches empezaron a instalarse en la región, ocupandola hasta mediados del siglo XIX.

\section{ARQUEOLOGIA E HISTORIA}

Presidio del Río Grande y la Ciudad Moderna de Guerrero

El poblado español a principio del siglo XVIII que eventualmente llegó a ser la ciudad moderna de Vicente Guerrero, empezó su existencia con el establecimiento del presidio militar 11 amado San Juan Bautista del Río Grande del Norte. El presidio y las misiones indias, situados cerca de unos importantes pasos de 1 Río Bravo, eran el punto de acceso a Texas.

En 1701 una Compañia Volante (caballería) constituída de 30 soldados, bajo las ordenes del capitán Diego Ramón, fue asignada a la protección de las misiones de San Juan Bautista y de San Francisco Solano que habían sido fundadas durante el año anterior por misioneros franciscanos. En 1702 se fundó la misión de San Bernardo en la cercenía.

En 1703 un presidio formal fue construido alrededor de la plaza de armas. Consistía de diez estructuras de piedra y adobe con tejado 11 ano. También por esta fecha fueron construidas alrededor del presidio numerosas casas pertenecientes a las familias de los militares y de los civiles quienes formaron un pequeño poblado fronterizo (Fig. 3). 
Aunque fuera originalmente fundado para la protección de las misiones, el presidio y la comunidad que creció a sus alrededores siguieron funcionando como bastión fronterizo aún después de la secularización de las misiones en 1797 y de su eventual abandono. El presidio del Río Grande perdió su pape1 militar a mediados del siglo XIX, cuando las unidades militares y el comercio internacional se desplazaron hacia las ciudades de Piedras Negras y Laredo.

El centro de Guerrero fue el sitio del Presidio del Rio Grande (Fig. 4). La Plaza de armas estaba rodeada por los edificios del presidio. Hoy día contiene un kiosko y un parque.

Pocos vestigios quedan de los edificios del presidio. Al este, aún permanece en pie la iglesia parroquial de San Juan Bautista (Fig. 5a). Aunque la construcción de esta iglesia se inció tempranamente en la historia del presidio, nu fue acabada sino hasta principios del sigle XIX. Mientras se construia la iglesia, una estructura mas pequeña servía de santuario para las familias militares y civiles. Las dos campanas de cobre que se ven en el campanario fueron colgadas allí en 1851 para comemorar el 150o aniversario del presidio. De costumbre, la iglesia se abre solo cuando el sacerdote de Piedras Negras viene a decir misa o a desempeñar otros servicios. Sin embargo, la llave de la iglesia se halla en el Palacio Municipal y se puede visitar el templo a petición.

En el lado occidental de la plaza, donde actualmente hay una escuela, se hallaban el cuartel general y el cuerpo de guardia. Los cuarteles de los soldados eran situados en el lado norte, donde ahora hay una residencia privada y una Cooperativa Familiar y también en el lado sur, donde queda hoy el Palacio Municipal. A poca distancia de la esquina noroeste de la plaza, en la calle Aldama, se halla la casa del capitán del presidio. Esta casa fue construida antes de 1776 y sirvió de residencia a los comandantes del presidio (Fig. 5b). 
A una cuadra al oeste de la plaza, en la calle Sánchez, se halla la casa Botello que es ahora una tienda y residencia privada, pero que fue una vez la casa del rayador del presidio. Otra estructura colonial que bien vale una visita esta en la calle Prieto, a una cuadra al sur de la plaza. Además, hay muchos otros edificios en toda la ciudad de Guerrero, algunos habitados, otros en ruinas, que datan de los siglos XVIII y XIX.

La calle más grande que atraviesa Guerrero es la calle Raúl López Sánchez, llamada en otros tiempos Calle Real. De la plaza, esta calle corre hacia el oeste pasando por el sitio de la misión San Juan Bautista, que queda a un kilómetro. El lugar está en la cumbre de un colina en terreno privado y no presenta ningún vestigio visible. Mas allá de la misión, el Camino Real se volvía hacia el sur en dirección de Monclova y de México, D.F.

El cementerio de la ciudad, situado en la Calle Abasolo, en el lado este de la ciudad, contiene criptas del período colonial. Aproximadamente a un kilómetro al norte del panteón está la misión de San Bernardo. Su posición esta marcada por una iglesia grande que nunca fue terminada. Mas allá de esta misión, el Camino Real cruzaba en ese tiempo el Río Bravo en los pasos Pacuache y Las Islas y se dirigía hacia San Antonio y las misiones al oriente de Texas.

A1 noroeste de Guerrero hay un lago alimentado por fuentes 11 amado Los Banaderos. Hay también dos ojos de agua 11 amados Las Brujas y Las Parritas que alimentaban la acequia Ciénega al norte de la ciudad. El agua de la acequia pasaba por dos caídas de agua, la segunda de las cuales fue dinamitada al principio de este siglo. A un lado de la presa dañada se halla la cantera que proveyó los bloques de travertina usados en la construccion de la mision San Bernardo. A poca distancia de la caída de agua, el visitante podrá ver la acequia tallada profundamente en la roca. Otra antigua cantera, la cual proveyó probablemente 
el material para la construcción de la misión San Juan Bautista, está situada cerca del ojo de agua de Las Brujas.

Un sistema de acequias alimentado por las fuentes y construido en tiempos coloniales aún lleva el agua al poblado.

\section{La Mision de San Juan Bautista}

San Juan Bautista fue la primera misión establecida en el área de Gateway. Fundada el Año Nuevo de 1700 por el capitán Diego Ramón y por los padres Antonio 01 ivares y Francisco Hidalgo, al principio fue situada cerca del presidio. Sin embargo, la posición exacta es dosconocida y nada queda de ella.

Por los años 1740, la misión fue traslada al oeste del presidio donde ocupó la cumbre de una colina a una distancia conveniente al poblado español (Fig. 4). Allí se quedó hasta que fue abandonada, poco tiempo después de la Guerra de Independicia de 1810. Poco a poco sus edificios fueron demolidos y la mayoría de los materiales de construcción sirvieron para edificar casas en la ciudad $y$ en los ranchos de 7 a vecindad. Hoy día solo una colina cubierta de nopales y de arbustos marca el sitio de la misión famosa.

En 1976, con el permiso del propietario, el sitio fue limpiado donde era necesario y excavaciones selectivas fueron 1levadas a cabo. Los resultados de estas exploraciones están mostrados en el plan del complejo de la misión (Fig. 6).

Gracias a la excavación selectiva de zanjas, huellas arquitectónicas más importantes fueron llevadas a la luz y registradas. En los lugares major conservados permanecen solamente fundaciones y pisos y algunas raras secciones de muro. Estos vestigios se hallaban enterrados bajo 304 pies de escombros y tierra (Fig. 7a). Registrados los hallazgos, el sitio fue cubierto de nuevo para proteger los descubrimientos. 
La iglesia de la misión era cruciforme y se enfrentaba al oeste. Los muros eran construidos de bloques de piedra tallado y de mamposteria consolidada con argamasa de cal y eran enyesados y encalados tanto por dentro como por fuera. Los pisos eran cubiertos de baldosas de cerámica. Al lado norte de la entrada se hallaba el campanario, en la base del cual había un bautisterio, y un altar mayor con dos altares menores a cada lado. La sacristía consistía de dos cuartos situados al sur del santuario.

A1 sur de la iglesia estaba el cuadrángulo del monasterio. En el interior del recinto se hallaban las habitaciones y las oficinas de los monjes residentes y también almacenes y talleres. Los edificios eran construidos de ladrillos de adobe sobre fundaciones de piedra y algunos de los pisos eran de mosáico.

A poca distancia al sur del cuadrángulo quedaba al granero donde era guardada la cosecha (maíz y frijol). Ningún muro queda de este edificio, pero se encontró un piso elevado de losas de piedra.

Más allá del granero había unos largos edificios que albergaban talleres como la herrería, la carpintería, y tal vez también la hilandería.

Una estructura alargada que contenía pequeños apartamentos para las familias indias formaba la parte sur de la misión y se extendía hacia el oeste. Solamente cimientos de piedra quedan de ellos. En la extremidad occidental había un bastión circular que formaba parte de las defensas de la misión (Fig. 7b).

La misión de San Bernardo

La misión de San Bernardo, fundada a principios del año 1702 por el capitán Diego Ramón y el padre Alonso González, estaba situada a poca distancia al noreste del Presidio del Río Grande (Fig. 4). Una iglesia grande y cruciforme fue construida por el padre Diego Jiménez durante los años de la década de 1760. La iglesia nunca 
fue terminada pero aún esta en pie, marcando el sitio de esta misión. Esta era la segunda iglesia construída en la misión. Todos los otros edificios han desaparecido después del abandono del complejo. La iglesia que queda fue renovada en 1975 por el Ministerio de Obras Públicas bajo la dirección del Departamento de Edificios Coloniales (INAH) (Fig. 8a).

Durante los años 1975-1976 se hicieron investigaciones arqueológicas a1 norte y al noreste de la iglesia. Los vestigios enterrados de los edificios de la misión fueron localizados gracias a las excavaciones selectivas. Los resultados de este trabajo han demostrado los planos de los edificios principales que componian la misión (Fig. 9).

A poca distancia al norte de la iglesia, habian dos filas de edificios largos los cuales albergaban a las familias indias y sus talieres. Solamente fueron halladas los cimientos de piedra bajo varias pulgadas de tierra (Fig. 8b).

Al noreste de la iglesia, más cimientos fueron encontradas y registradas. En el área grande entre los dos grupos de edificios, donde hoy en día es lugar de recreación, se hallaba el cuadrángulo de la misión. No fue hallado ninguna evidencia de recinto y es posible que no haya habido ninguno.

El grupo oriental de estructuras comprendía la iglesia original de San Bernardo y otras estructuras que fueron las habitaciones de los misioneros, oficinas, almacenes y talleres.

La iglesia original tenía una estructura sencilla lineal y probablemente fue usada hasta que la misión fue abandonada. No se sabe si la iglesia que aún esta de pie fue jamás consagrada y usada para los ritos.

Completadas las exploraciones y los registros, gran parte de los vestigios de nuevo fueron cubiertos de tierra para ser conservados. 
La Misión de San Francisco Solano

Poco se sabe de esta misión que fue fundada solo dos meses después de la misión San Juan. Se cree que el sitio de esta misión fuera al noroeste de Guerrero (Fig. 4), pero no quedan de ella ningunos rastros arquitectónitos para verificarlo y no se han emprendido exploraciones arqueológicas.

Fundada por el capitán Diego Ramón y el padre Antonio 01ivares, esta misión se quedó en la región de Gateway solo por tres años. Después de una serie de traslados acabó por fijarse en las orillas del río San Antonio en Texas, donde fue renombrada Misión de San Antonio de Valero y posteriormente conocida como el Alamo. 
Figure 1. Map Showing Location of Villa de Guerrero and the Gateway Area.

Figura 1. Mapa que Muestra la Localizacion de la Villa de Guerrero y el Area de el Paso. 
23

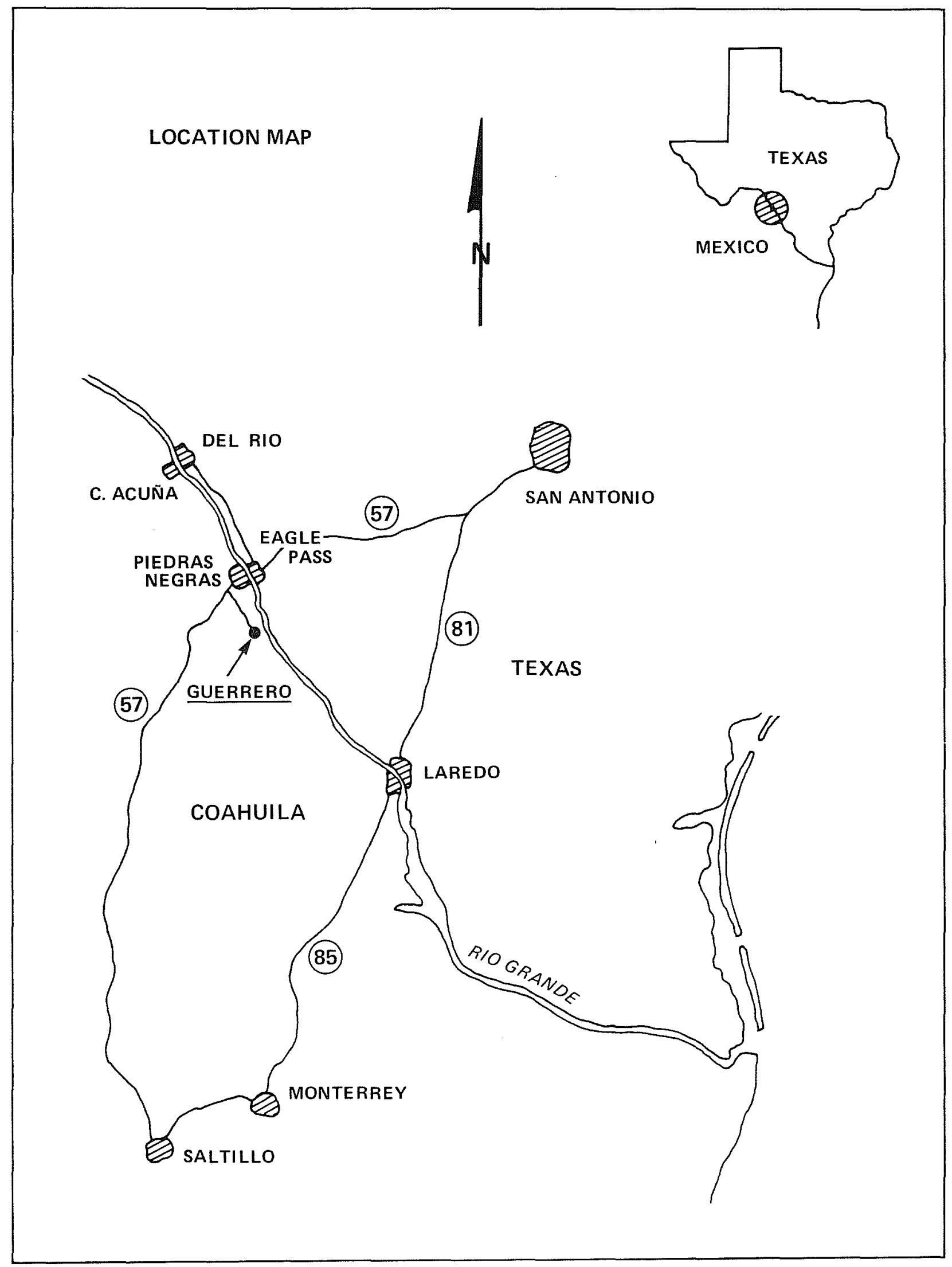


Figure 2. Artifact Examples Collected from Area Survey and Mission Excavations. a, metal pot handle; b, scissors; $c$, kitchen knife; d-e, metal crucifixes; f-h, metal arrow points; $i-k$, flint arrow points; $1-p$, flint dart points.

Figura 2. Ejemplos de Artefactos Encontradas Superficialmente $y$ en las Excavaciones de las Misiones. a, asa de metal de una jarra; b, tijeras; c, cuchillo de cocina; d-e, crucifijos de metal; f-h, puntas de flecha de metal; $i-k$, puntas de flecha de silice; $1-p$, puntas de lanza de silice. 


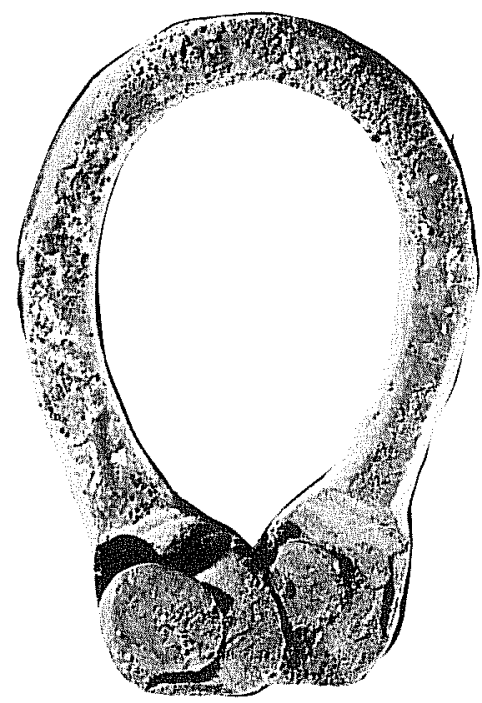

a
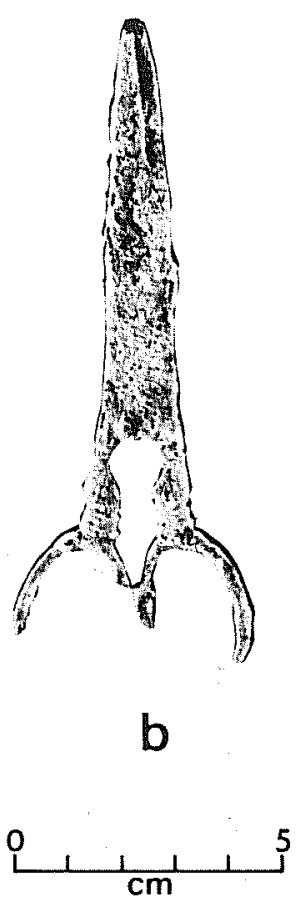
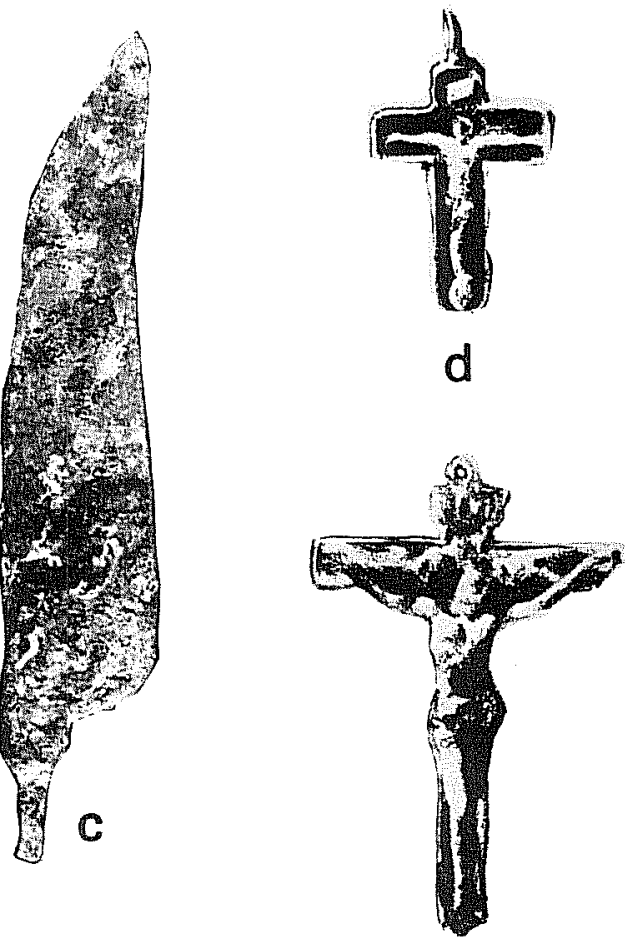

e

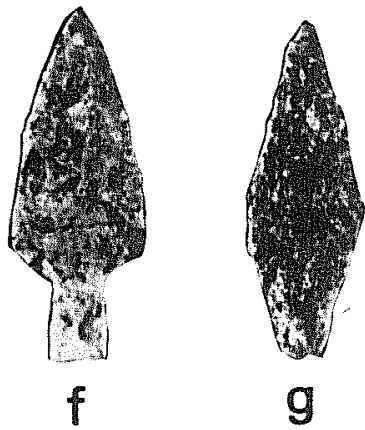

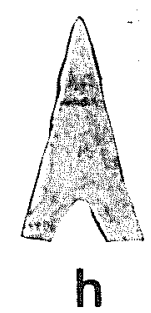

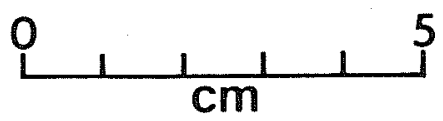

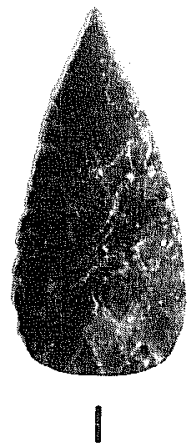
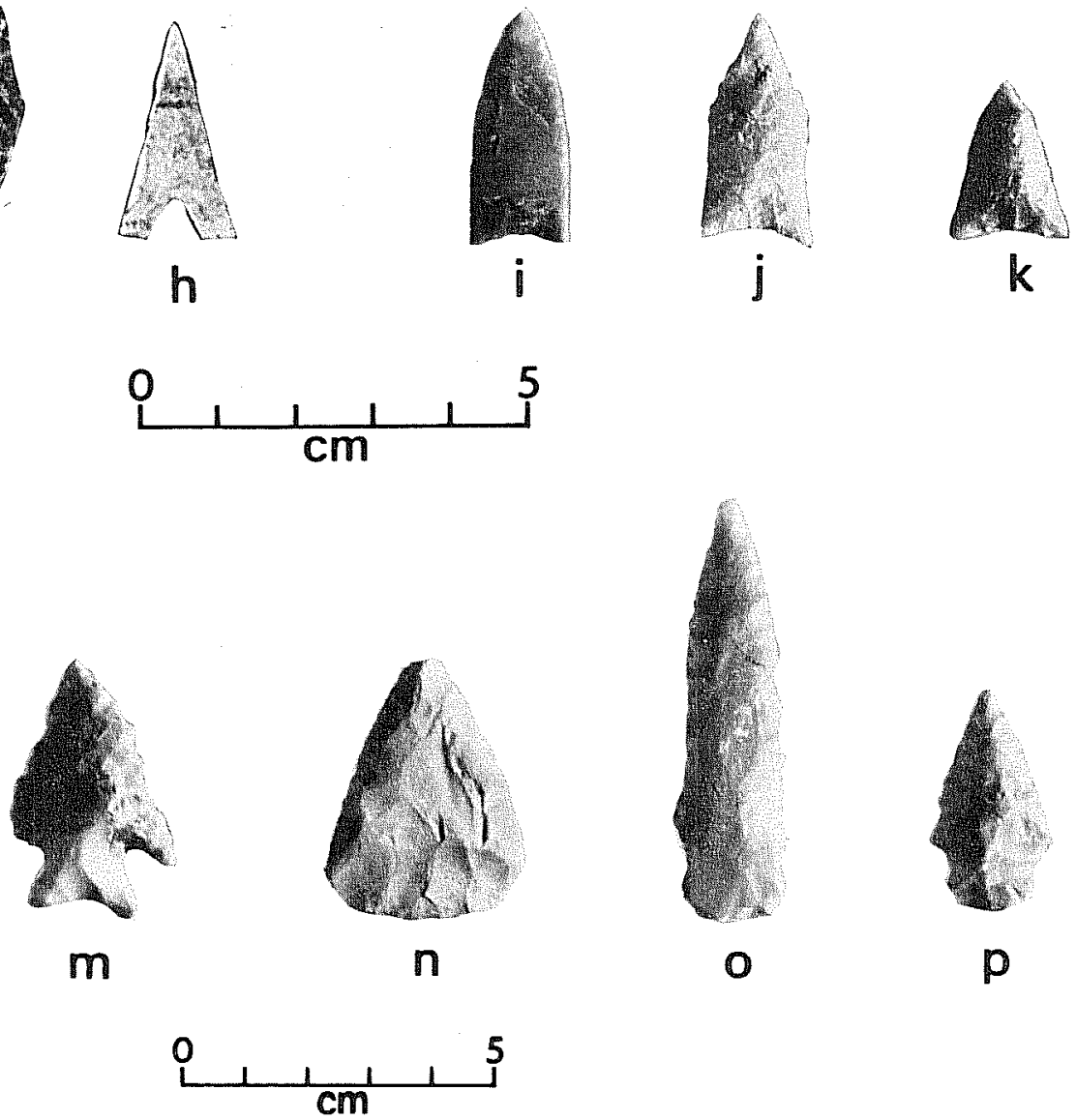
Figure 3. Map of Presidio de San Juan Bautista del Rio Grande. Drawn in 1767 by José de Urrutia.

Figura 3. Mapa del Presidio de San Juan Bautista del Rio Grande. Trazada en 1767 por José de Urrutia. 


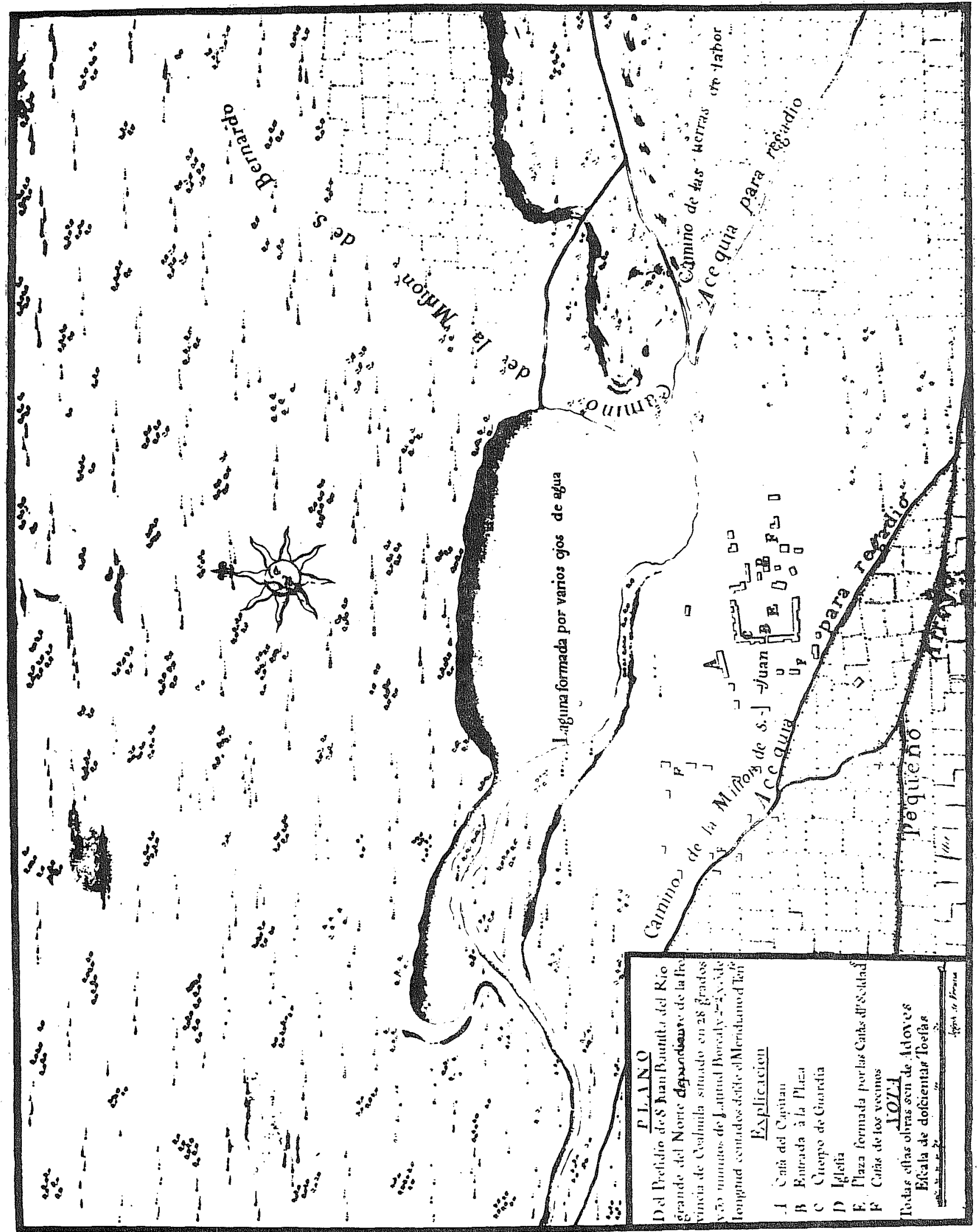


Figure 4. Street Map of Villa de Guerrero. Locations of the presidio and missions with respect to the modern town are shown.

Figura 4. Mapa de las Calles de la Villa de Guerrero. Los sitios del presidio y de las misiones con respecto a la ciudad moderna están mostrados. 


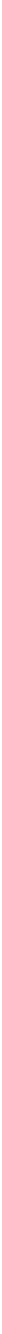


Figure 5. Presidio Period Structures in Guerrero. a, San Juan Bautista parish church; b, presidio captain's house.

Figura 5. Estructuras del Periodo del Presidio en Guerrero. a, la iglesia parroquial de San Juan Bautista; b, la casa del capitán del presidio. 


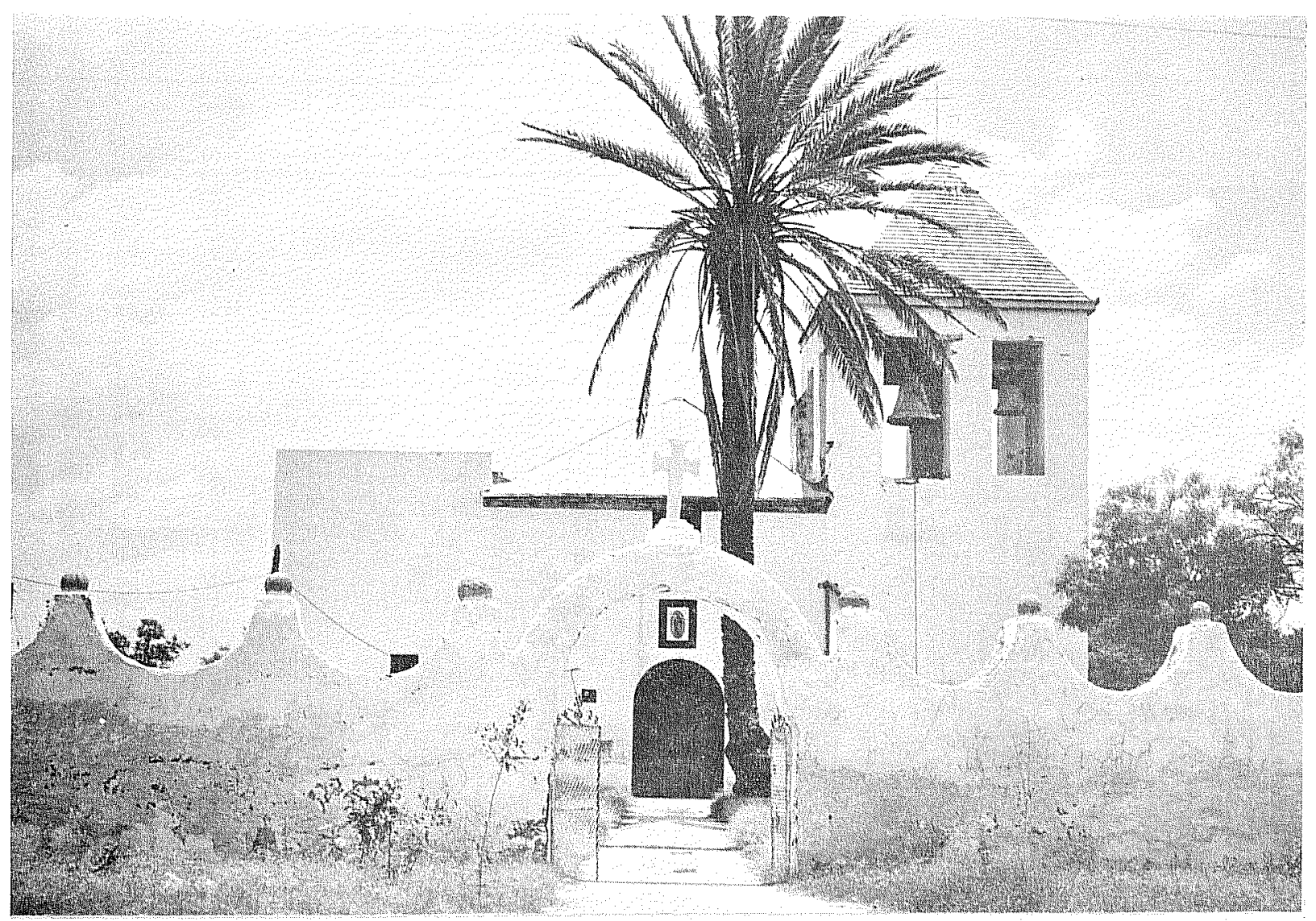

2

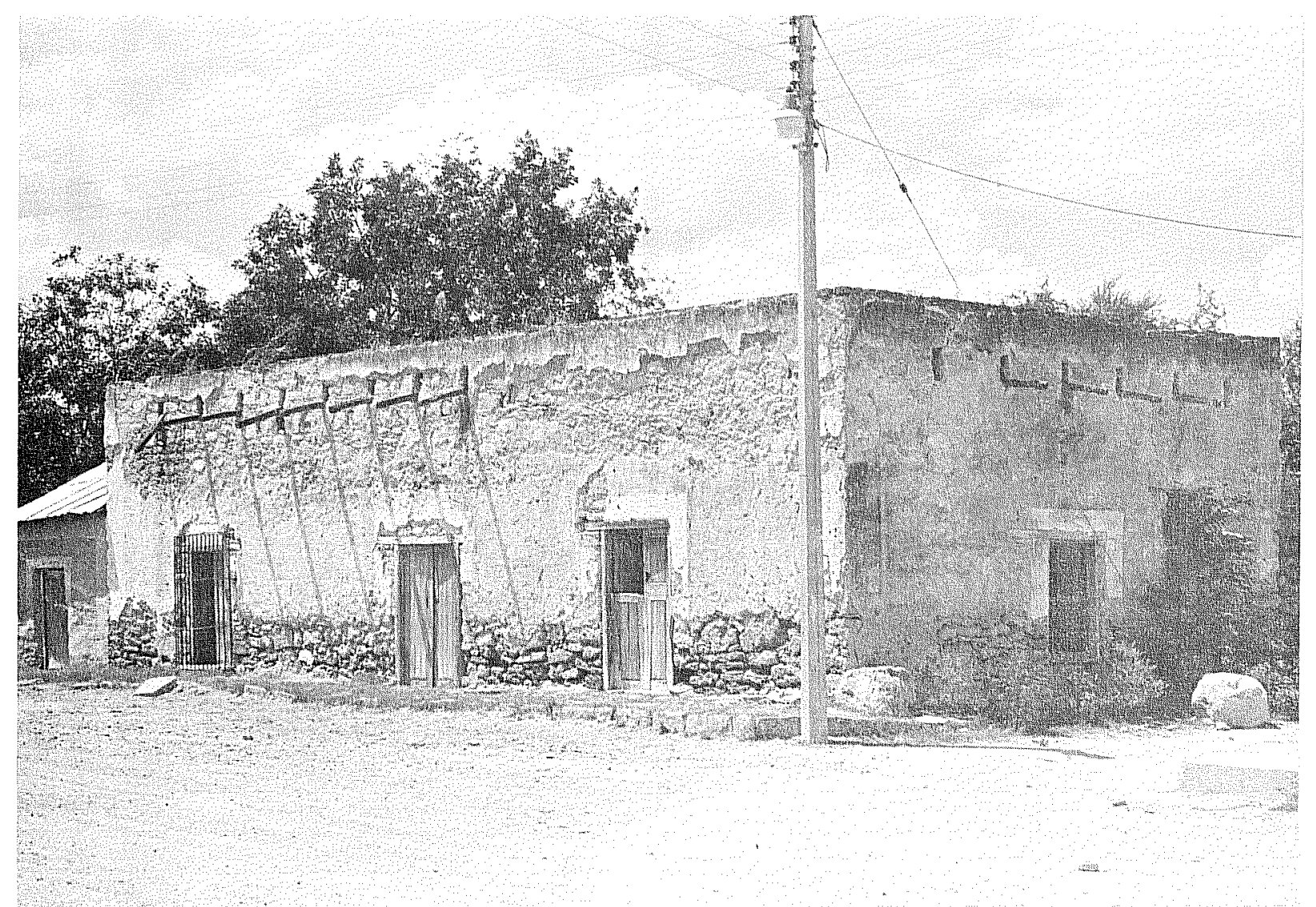


Figure 6. Plan of Mission San Juan Bautista. Ground plan of structural remains uncovered during 1976 excavations.

Figura 6. Plan de la Misión de San Juan Bautista. Planta de los vestigios estructurales llevados a la luz durante las exploraciones de 1976. 


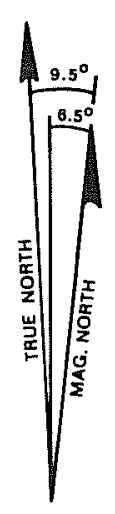

\section{SAN JUAN BAUTISTA MISSION} GUERRERO, COAHUILA, MEXICO

PLAN

J. Eaton, T. Hester June 1976

Note:

Exact locations of doorways and dividing walls uncertain except as shown.
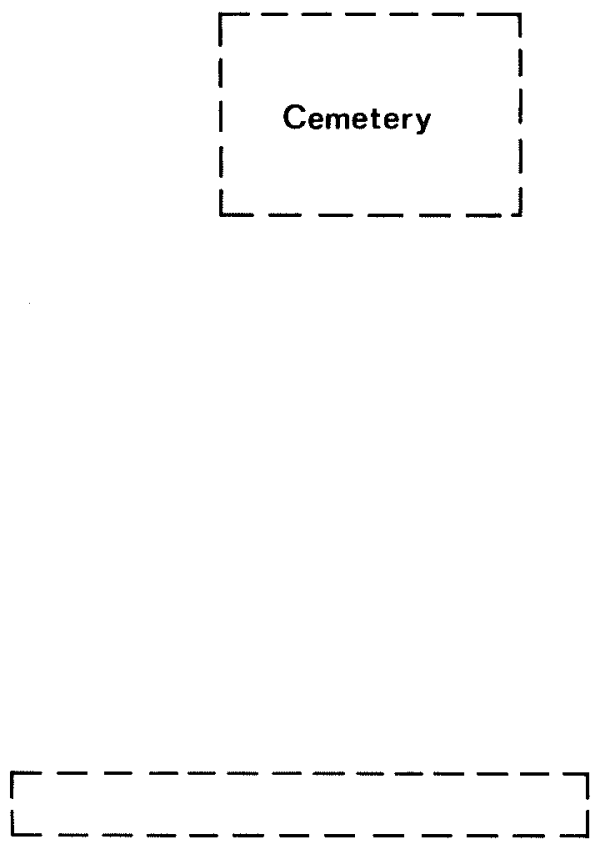

Low Linear Mounds

(Probable Indian Housing)

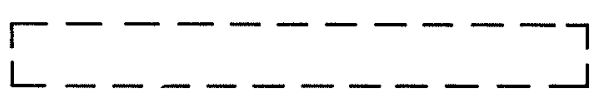

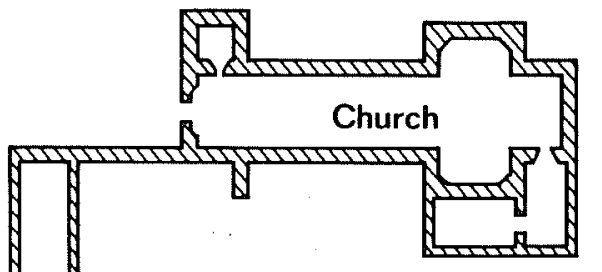

Quadrangle

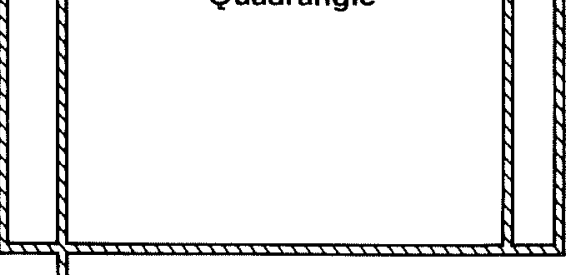

Granary

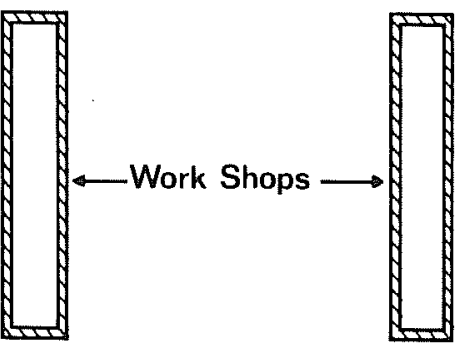

Indian Housing (Divided into Apartments)

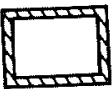


Figure 7. Mission San Juan Bautista. a, remains of the main portal; b, view of the bastion foundation.

Figura 7. Misión de San Juan Bautista. a, restos de entrada principal; b, vista de los cimientos de la torreón. 


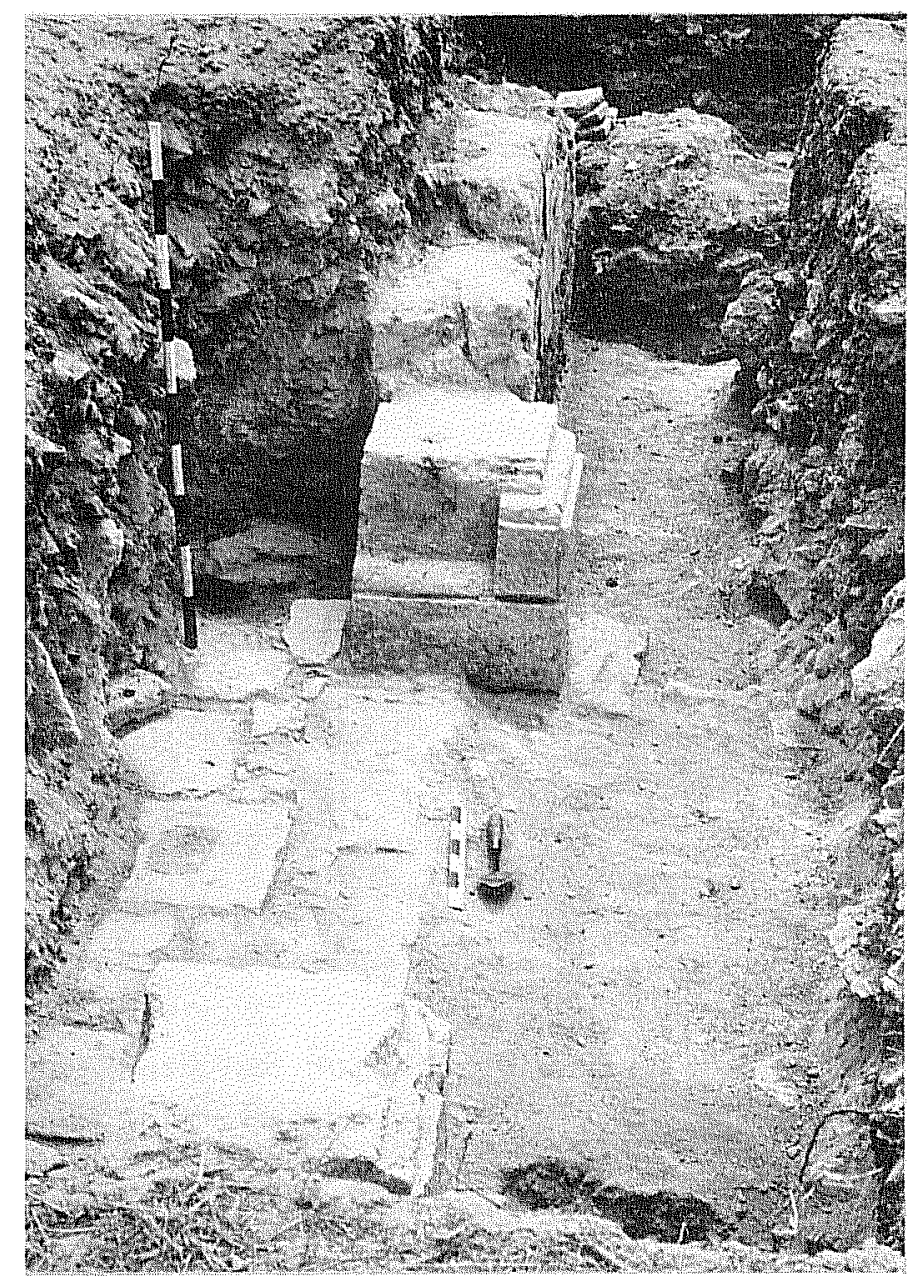

a

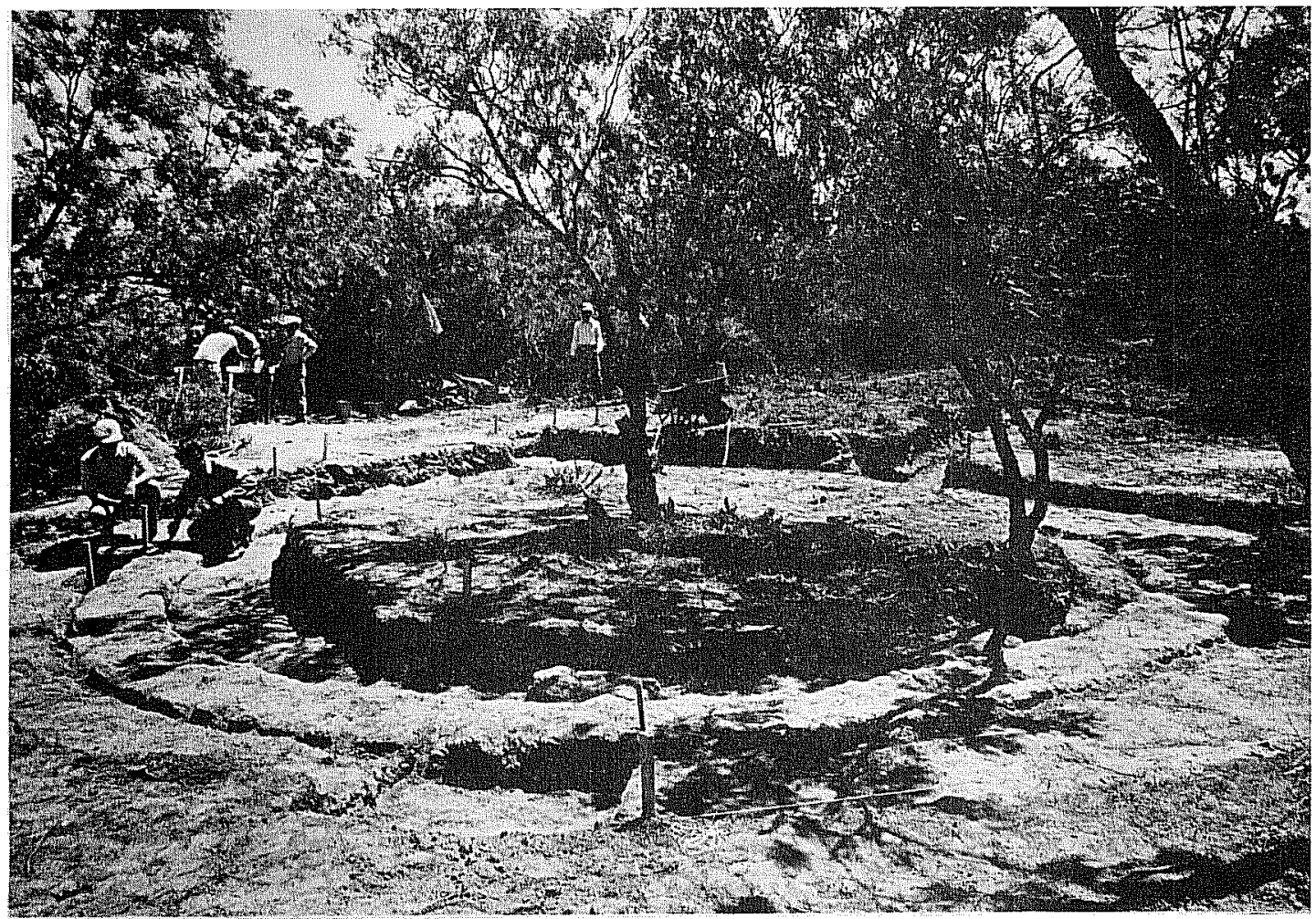


Figure 8. Views of Mission San Bernardo. a, San Bernardo Mission Church constructed during the 1760s; $b$, excavating remains of Indian apartments north of church.

Figura 8. Vista de la Misión de San Bernardo. a, Iglesia de la Misión de San Bernardo construida en la decada de 1760; b, excavación de los vestigios de los apartamentos Indios al norte de la iglesia. 

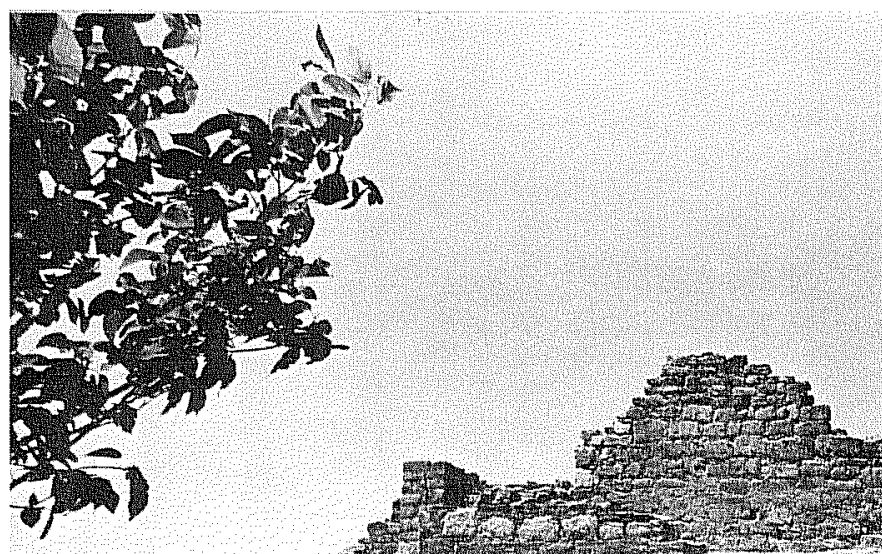

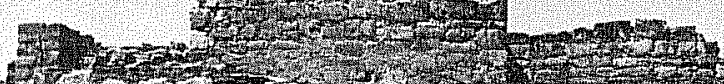

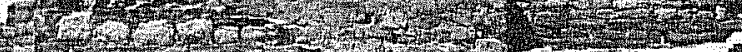

1 97
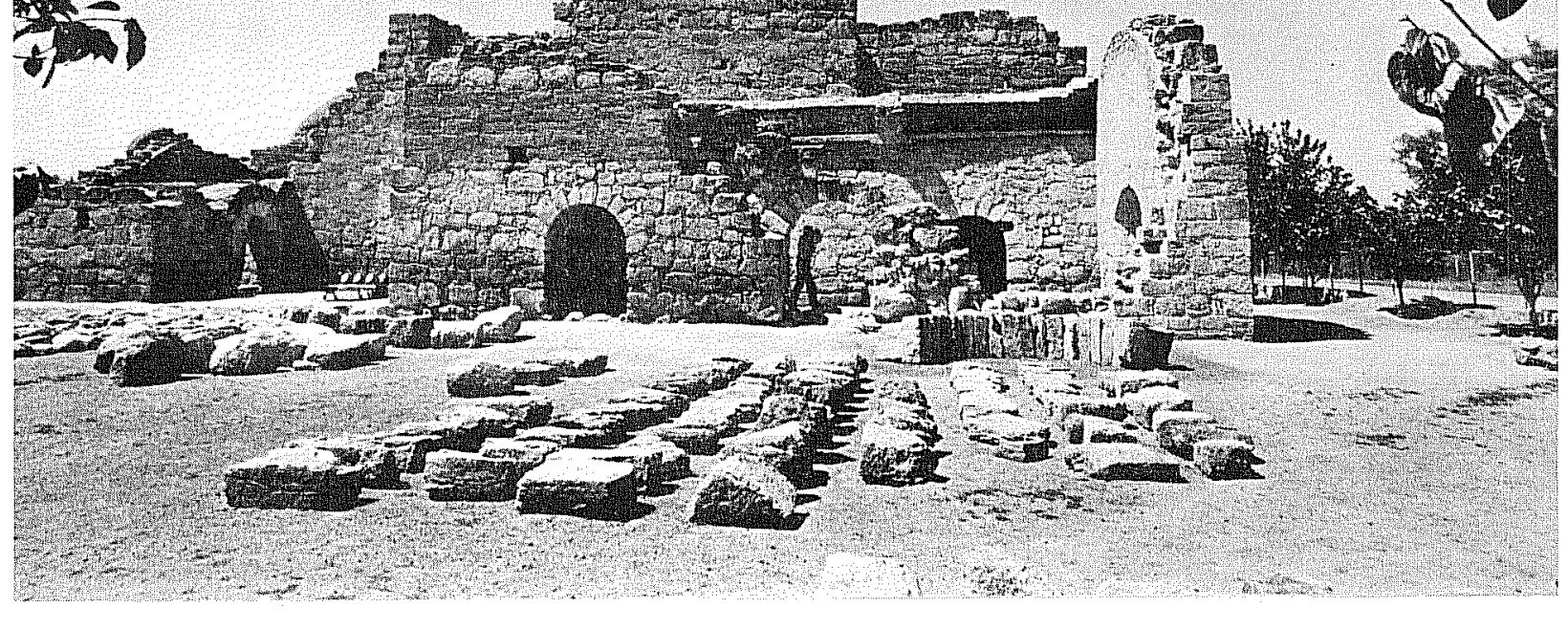

a

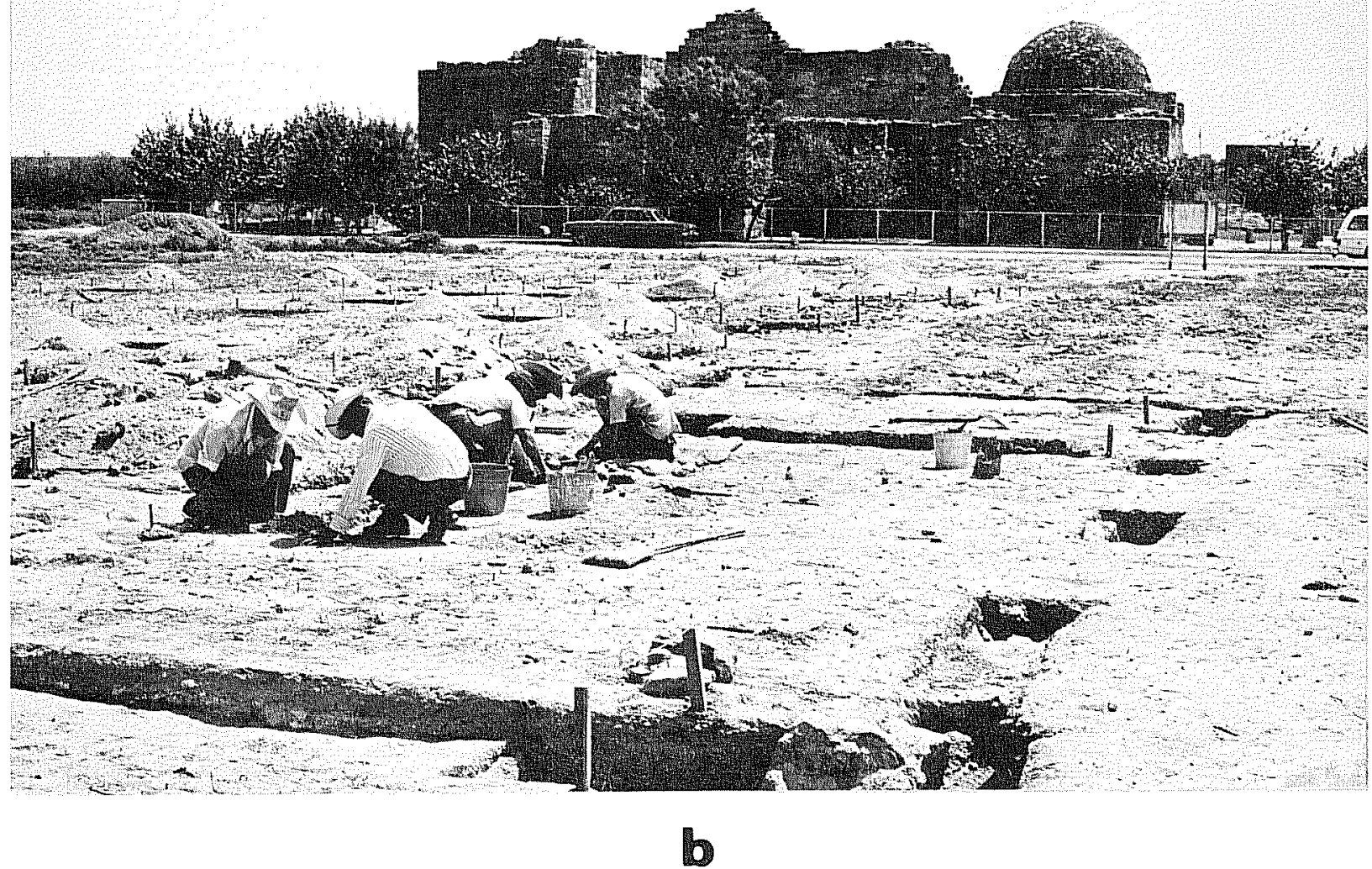


Figure 9. Plan of Mission San Bernardo. Ground plan of structural remains north of church uncovered during 1975 and 1976 excavations.

Figura 9. Plan de la Misión de San Bernardo. Planta de los vestigios estructurales al norte de la iglesia llevados a la luz durante las exploraciones de 1975 y 1976. 

SUGGESTED READING LIST

Bannon, John Francis (Editor)

1964 Bolton and the Spanish Borderlands. University of Oklahoma Press, Norman.

Botee1, G. Aurora

1956 Datas Historicos sobre la Fundacion de la mision de San Bernardo y la Villa de Guerrero, Coahuila, Antes Real Presidio del Rio Grande del Norte. Piedras Negras.

Morfi, Fray Juan Agustin

1950 Descripcion del Territorio del Real Presidio de San Juan Bautista del Rio Grande del Norte, y su jurisdiccion Año de 1778.

Wedd7e, Robert S.

1968 San Juan Bautista: Gateway to Spanish Texas. University of Texas Press, Austin.

ADDENDUM

After completion of the archaeological excavations and documentation at the mission sites, the architectural remains were reburied in order to preserve them. However, during September, 1979, an unfortunate event took place at the site of Mission San Juan Bautista. A man operating a bulldozer entered the mission site for the purpose of looting, and in the process caused extensive damage to the buried remains. The man was apprehended and placed in jail, but not before much destruction was done.

The reader and visitor to the site of Mission San Juan Bautista should be aware that the badly disturbed condition now seen there results from malicious looting and not from the archaeological work.

Mr. John Stockley of Quemado, Texas, has kindly provided documentation of the destruction done at Mission San Juan Bautista. This documentation (including photographs, sketches, and newspaper clippings) is on file at the Center for Archaeological Research, The University of Texas at San Antonio. 